\title{
ANALISIS KEKRITISAN ELEMEN BAKAR REAKTOR KARTINI
}

\author{
Edi Trijono Budisantoso \\ Puslibang Teknologi Maju Batan \\ Jl. Babarsari Kotak Pos 1008, Yogyakarta 55010
}

\begin{abstract}
ABSTRAK
ANALISIS KEKRITISAN ELEMEN BAKAR REAKTOR KARTINI. Telah dilakukan analisis kekritisan elemen bakar reaktor Kartini dengan menggunakan program WIMSD4. Analisis kekritisan dikerjakan dengan mendefinisikan sel bahan bakar sebagai elemen bakar yang dikelilingi air pendingin dengan ruji-ruji yang bervariasi dari $2 \mathrm{~cm}$ sampai dengan $5 \mathrm{~cm}$. Kekritisan sel ditentukan berdasarkan pada hasil perhitungan faktor multiplikasi neutron sel oleh program WIMSD4. Dikatakan kritis atau superkritis apabila faktor multiplikasi neutron sel sama dengan 1 atau lebih. Dari variasi ruji-ruji sel dalam input WIMSD4 diperoleh variasi faktor multiplikasi neutron sel yang dihasilkan oleh program WIMSD4. Berdasarkan pada hubungan antara ruji-ruji sel dengan faktor multiplikasi neutron yang dihasilkannya dapat ditetapkan batas ukuran ruji-ruji sel yang menghasilkan kondisi sel subkritis. Dari hasil perhitungan dapat diperoleh kesimpulan bahwa elemen bakar reaktor Kartini akan bersifat subkritis dengan $k_{\sim}=0.94$ apabila ditempatkan pada kisi-kisi sel yang masing-masing selnya mempunyai ruji-ruji minimum $4.5 \mathrm{~cm}$. Fasilitas tempat penyimpanan elemen bakar di reaktor Kartini seluruhnya mempunyai kisi-kisi sel yang ruji-ruji minimumnya lebih kecil dari hasil perhitungan sub kritikalitas sel, akan tetapi kapasitas elemen bakar dari tiap tempat penyimpanannya jauh dibawah batas massa kritis dari volume tempat penyimpanan elemen bakarnya. Dengan demikian tempat penyimpanan elemen bakar dapat dipandang memenuhi syarat subkritikalitas yang ditetapkan.
\end{abstract}

\section{ABSTRACT}

THE CRITICALITY ANALYSIS OF KARTINI REACTOR FUEL ELEMENT. The criticality of Kartini reactor fuel element has been analyzed by using WIMSD4 code. The criticality is analyzed by defining fuel cell as a fuel rod surrounded by water in various radiuses from $2 \mathrm{~cm}$ to $5 \mathrm{~cm}$. WIMSD4 calculates neutron multiplication factor in the cell to determine cell criticality. It is called critical or supercritical if the cell multiplication factor is equal or greater than 1. From the various cell radius in the input WIMSD4 can be obtained various cell multiplication factor related to the cell radius. Base on the relation between cell radiuses to the cell multiplication factor, can be obtained the cell radius, which produce cell sub criticality condition. From that calculation can be concluded that Kartini Fuel element will be sub critical with $K_{\sim}=0.94$ if it is placed in the fuel lattice cell in radius minimum $4.5 \mathrm{~cm}$. All of the fuel storage facility in the Kartini reactor has a smaller radius cell than the minimum cell radius under calculation, but the fuel capacity of fuel storage is far below the critical mass of the fuel storage volume. So all of the fuel storage is under the determination of sub criticality.

\section{PENDAHULUAN}

Aper nalisis kekritisan elemen bakar sebagai perhitungan reaktor atau perhitungan perencanaan tempat elemen bakar telah dilakukan sejak reaktor direncanakan. Analisis kekritisan mulai dari perhitungan tangan dengan menggunakan teori diffusi satu kelompok satu dimensi sampai dengan analisis dengan menggunakan paket program komputer telah dicoba. Dari hasil analisis tersebut telah diperoleh sarana tempat penyimpanan elemen bakar baru, fasilitas irradiator gamma dan gamma scanning maupun rak tempat penyimpanan elemen bakar bekas yang kesemuanya tidak menyimpang dari analisis kekritisan yang dilakukannya.

Pada tulisan ini dicoba analisis kekritisan dengan menggunakan program WIMSD4 untuk analisis satuan sel bahan bakar. Analisis ini bertujuan untuk 
mendapatkan batas sub-kritikalitas dari sel bahan bakar yang akan dikembangkan menjadi syarat batas tempat penyimpanan elemen bakar. WIMSD4 adalah program perhitungan multi sel yang menggunakan persamaan transport neutron untuk menentukan distribusi flux di dalam selnya. WIMSD4 diperlengkapi dengan pustaka data tampang lintang mikroskopik dalam 69 kelompok energi neutron.

Dalam analisis, program WIMSD4 digunakan untuk menentukan faktor multiplikasi neutron (K) sel bahan bakar yang didefinisikan, dan menentukan buckling kritis dari konstruksi sel yang didefinisikan. Ukuran buckling kritis dapat digunakan untuk menentukan ruji-ruji kritis sel yang mencerminkan batas ukuran kritis dari gabungan sel yang didefinisikan. Ruji-ruji kritis ini bersama-sama dengan nilai faktor multiplikasi neutronnya dapat digunakan untuk menentukan batasan sub-kritis dari sekumpulan elemen bakar dalam tempat penyimpanannya.

Diharapkan analisis kekritisan berdasarkan pada analisis satuan sel dapat memberikan batas geometri sub-kritis yang lebih teliti.

\section{DASAR TEORI}

Neutron dalam elemen bakar dapat berkembang biak karena ada inti bahan fisil yang dapat menyerap neutron thermal dan membelah menghasilkan 2-3 neutron baru sebagai neutron cepat yang siap termoderasi di dalam mediumnya untuk kemudian menjadi neutron thermal yang kemudian diserap oleh inti bahan fisil selanjutnya dan menghasilkan neutron baru berikutnya. Fenomena ini disebut sebagai reaksi berantai yang daur regenerasi neutronnya dapat dinyatakan sebagai faktor multiplikasi neutron yang dituliskan sebagai berikut:

$$
K=\eta \varepsilon L_{f} p L_{t} f
$$

dengan ketentuan

$L_{f}=$ faktor tidak bocor sebagai neutron cepat

$L_{t}=$ faktor tidak bocor sebagai neutron thermal

$\varepsilon=$ faktor pembelahan cepat $=\frac{\text { pembelahan total }}{\text { pembelahan thermal }} \geq 1$

$p=$ faktor keboleh - jadian bebas resonansi

$\eta=$ faktor pembelahan thermal $=v \frac{\sigma_{f}^{F}}{\sigma_{a}^{F}}$

$f=$ faktor penggunaan thermal $=\frac{\Sigma_{a}^{F}}{\Sigma_{a}^{F}+\Sigma_{a}^{0}}$

Apabila medium bahan bakarnya tak berhingga besar maka nilai $L_{t}=L_{f}=1$ sehingga faktor multiplikasi neutron menjadi $K_{\sim}=\varepsilon p \eta f \quad$ yang nilainya ditentukan sepenuhnya oleh komposisi material dalam bahan bakar.

Untuk melihat hubungan antara $\mathrm{K}$ dengan geometri elemen bakarnya maka digunakan teori diffusi neutron yang disederhanakan untuk neutron dalam satu kelompok energi dengan medium homogen.

Berdasarkan teori diffusi, kekekalan neutron dalam medium bahan bakar dapat dinyatakan sebagai berikut:

$$
\begin{aligned}
& K_{\sim} \varphi \Sigma_{a}=-D \nabla^{2} \varphi+\varphi \Sigma_{a} \\
& D \nabla^{2} \varphi-\varphi \Sigma_{a}+K_{\sim} \varphi \Sigma_{a}=0 \\
& D \nabla^{2} \varphi-\left(K_{\sim}-1\right) \varphi \Sigma_{a}=0
\end{aligned}
$$

Persamaan (2) menyatakan kesetaraan neutron antara laju produksi terhadap proses diffusi dan laju serapan thermalnya di dalam bahan bakar bilamana keadaan tepat kritis.

$$
B_{m}^{2}=\frac{\Sigma_{a}}{D}\left(K_{\sim}-1\right)=\frac{K_{\sim}-1}{L^{2}}
$$

Apabila didefinisikan buckling material sebagai berikut:

dengan ketentuan

$\Sigma_{a}=$ tampang lintang makroskopis material teras

$D=k o e f i s i e n$ diffusi material teras

$L^{2}=$ luas diffusi

$B_{m}^{2}=$ buckling material 
maka persamaan (2) dapat dituliskan kembali sebagai berikut:

$$
\nabla^{2} \phi+B_{m}^{2} \phi=0
$$

Persamaan (4) adalah persamaan difusi neutron secara umum. Apabila dituliskan dalam koordinat silinder maka diperoleh persamaan sebagai berikut:

$$
\frac{\delta^{2} \varphi}{\delta r^{2}}+\frac{1}{r} \frac{\delta \varphi}{\delta r}+\frac{\delta^{2} \varphi}{\delta r^{2}}+B_{m}^{2} \varphi=0
$$

Persamaan (5) pempunyai penyelesaian sebagai berikut:

$$
\begin{aligned}
& \varphi(r, z)=A J_{0} \frac{2.405 r}{R^{\prime}} \operatorname{Cos}\left(\frac{\pi z}{H^{\prime}}\right) \\
& B_{g}^{2}=\left(\frac{2.405}{R^{\prime}}\right)^{2}+\left(\frac{\pi}{H^{\prime}}\right)^{2}
\end{aligned}
$$

Pada keadaan tepat kritis, buckling geometri hasil penyelesaian pada persamaan (6) sama dengan buckling material pada persamaan (3) dan dapat dituliskan sebagai berikut:

$$
B_{g}^{2}=B_{m}^{2}>0 \quad \text { (kondisi kritis) }
$$

Persamaan (7) menjadi syarat terjadinya keadaan tepat kritis dari suatu kumpulan elemen bakar yang membentuk geometri tertentu.

\section{Analisis Kekritisan}

Persamaan (7) menunjukkan syarat kekritisan neutronik dari suatu kumpulan elemen bakar yang membentuk bangun geometri tertentu. Buckling material menunjukkan kemampuan komposisi material dalam memproduksi neutron sedangkan Buckling geometri menunjukkan keboleh- jadian neutron bocor oleh karena faktor geometrinya. Apabila Buckling material lebih besar dari Buckling geometri maka kumpulan elemen bakar akan menjadi super kritis yang memungkinkan berlangsungnya reaksi berantai dengan populasi neutron yang makin banyak sedangkan kalau buckling geometri lebih besar dari buckling materialnya maka kondisi akan menjadi sebaliknya. Keadaan ini dapat dijadikan syarat batas kekritisan untuk menentukan batas ukuran geometri tempat penyimpanan elemen bakar reaktor dimana masing-masing elemen bakar dapat dipandang sebagai sel bahan bakar. Buckling material ditentukan melalui analisis komposisi material dalam sel bahan bakar yang didefinisikan.
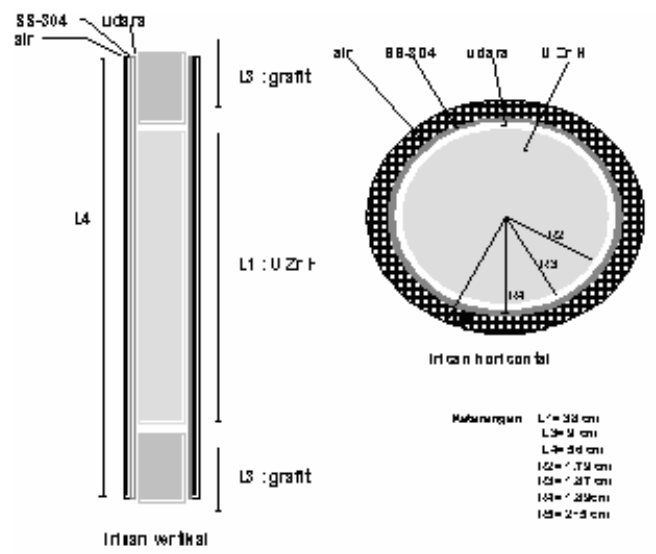

Gambar 1. Bemen bakar sebagai sel teras reaktor Kartini

Pada elemen bakar reaktor Kartini, sel bahan bakar yang merupakan konstruksi terkecil dari teras reaktor dapat didefinisikan sebagai batang elemen bakar yang dikelilingi air pendingin. Bentuk geometri sel dapat diuraikan seperti pada Gambar 1.

Dengan menggunakan Gambar 1 ini dapat diuraikan konstruksi heterogen material dalam sel bahan bakar. Program WIMSD4 menerima masukan konstruksi sel beserta heterogenitas material dalam sel dan menterjemahkannya dalam bentuk region-region homogenisasi material dalam dua dimensi koordinat silinder $(r, z)$. Dengan menggunakan metode kebolehjadian tumbukan, program WIMSD4 menyelesaikan persamaan transport untuk menentukan distribusi neutron dalam tiap region dan menghitung faktor multiplikasi neutron 
dalam selnya. Dengan menggunakan perintah 'BUCKLING SEARCH' program WIMSD4 dipakai untuk menghitung buckling kritis pada sel yang didefinisikan. Apabila diketahui buckling kritisnya maka geometri kritis daripada sel yang didefinisikan dapat ditentukan dengan menggunakan persamaan (6). Geometri kritis tersebut menunjukkan batas ukuran minimum gabungan sel yang didefinisikan mempunyai kebolehjadian menjadi kritis. Dari hubungan antara geometri kritis dengan geometri sel yang didefinisikan ini dapat diperoleh jumlah elemen bakar yang kemungkinannya dapat menjadi kritis apabila bersama-sama ditempatkan dalam wadah yang geometrinya adalah kelipatan dari geometri sel yang didefinisikan.

Dalam analisis kekritisan ini dibuat tidak ada penggabungan sel kearah aksial sehingga buckling geometri aksial dapat dibuat konstan dan penggabungan sel kearah radial akan merubah buckling geometri radialnya. Dari hasil perhitungan BUCKLING SEARCH oleh program WIMSD4 digunakan hasil perhitungan buckling radial dengan buckling aksial yang ditetapkan. Untuk analisis kekritisan ini akan dibuat variasi ruji-ruji sel bahan bakar mulai dari $2.0 \mathrm{~cm}$ sampai dengan $5.0 \mathrm{~cm}$, dengan merubah ketebalan medium air disekeliling batang elemen bakar dalam sel. Program WIMSD4 akan menentukan faktor multiplikasi neutron dalam sel dan hasil perhitungan buckling.

Dengan menggunakan persamaan (6) dapat dihitung ruji-ruji kritis sel.

Apabila dikorelasikan antara ruji-ruji sel dan ruji-ruji kritis sel akan dapat diperoleh jumlah elemen bakar yang mempunyai kebolehjadian kritis apabila digabungkan dalam kisi-kisi sel yang didefinisikannya.

Apabila dibuat korelasi antara ruji-ruji sel, ruji-ruji kritis sel, jumlah kritis elemen bakar dan faktor multiplikasi neutronnya, maka akan diperoleh sebuah tabel yang menginformasikan batas sub-kritis sel hasil perhitungan WIMSD4 yang dapat digunakan untuk menentukan kisi-kisi elemen bakar dalam penyimpanannya.

\section{PELAKSANAAN PERHITUNGAN}

Elemen bakar reaktor Kartini mempunyai spesifikasi material tertentu dan dapat diuraikan sebagai berikut

Jenis perangkat : Elemen Bakar Reaktor TRIGA

Material Kelongsong : SS304

Material Bahan Bakar : 8.5\% U dalam alloy

$\mathrm{U}-\mathrm{Zr}-\mathrm{H}_{1.6}$

Pengkayaan U-235 : 20\%

Berat U-235 : 38 gr/elemen.

Elemen bakar reaktor Kartini sebagai sel bahan bakar ditampilkan pada Gambar 1 . Apabila material elemen bakar diuraikan sebagai fungsi region sel, maka diperoleh uraian material dalam Tabel 1. dan Tabel 2 berikut:

Tabel 1 dan Tabel 2, merupakan data yang diperlukan untuk masukan program WIMSD4. Program WIMSD4 adalah program perhitungan kisi-kisi sel yang menggunakan teori transport untuk menghitung distribusi fluks neutron dalam sel.

Dalam perhitungan ini program WIMSD4 diperintah untuk menyelesaikan persamaan transport berdasarkan pada kebolehjadian tumbukan dalam medium silinder yang tertentu arah radial dan aksialnya seperti didefinisikan dalam selnya. 
Tabel 1. Data komposisi material dan ukuran fisik sel bahan bakar reaktor KARTINI.

\begin{tabular}{|c|c|c|c|c|}
\hline No & $\begin{array}{l}\text { Nama kelompok } \\
\text { material }\end{array}$ & $\begin{array}{l}\text { Komposisi } \\
\text { material }\end{array}$ & $\begin{array}{l}\text { Ukuran fisik region } \\
\text { (cm) }\end{array}$ & $\begin{array}{c}\text { Kategori region sel } \\
\text { dalam program } \\
\text { WIMSD4 }\end{array}$ \\
\hline 1 & Daging bahan bakar & $100 \%$ UZrHx & $\begin{array}{l}\text { Panjang = 38,42 } \\
\text { Diameter luar }=3,58 \\
\text { Diameter dalam=0,576 }\end{array}$ & Bahan bakar \\
\hline 2 & Celah udara & $\begin{array}{c}76.6 \% \mathrm{~N}_{2} 23.4 \% \\
\mathrm{O}_{2}\end{array}$ & $\begin{array}{l}\text { Panjang = 57,5 } \\
\text { Diameter luar= 3,74 } \\
\text { Diameter dalam = 3,58 }\end{array}$ & Kelongsong \\
\hline 3 & Reflektor aksial & $100 \%$ Grafit & $\begin{array}{l}\text { Panjang = } 2 \times 9,5 \\
\text { Diameter luar = 3,58 } \\
\text { Diameter dalam = 0,0 }\end{array}$ & Kelongsong \\
\hline 4 & Kelongsong SS-304 & $\begin{array}{c}70.92 \% \mathrm{Fe}, 19 \% \\
\mathrm{Cr}, 10 \% \mathrm{Ni}, 0.08 \% \\
\mathrm{C}\end{array}$ & $\begin{array}{l}\text { Panjang = 57,5 } \\
\text { Diameter luar= 3,78 } \\
\text { Diameter dalam = 3,74 }\end{array}$ & Kelongsong \\
\hline 5 & Pendingin & $100 \%$ Air $\left(\mathrm{H}_{2} \mathrm{O}\right)$ & $\begin{array}{l}\text { Panjang }=57,5 \\
\text { Diameter dalam = 3,78 } \\
\text { Diameter luar divariasi } \\
\text { Dari } 2 \mathrm{~cm} \text { sampai dengan } \\
5 \mathrm{~cm} .\end{array}$ & Pendingin \\
\hline
\end{tabular}

Tabel 2. Komposisi material dalam sel bahan bakarsebagai input WIMSD4.

\begin{tabular}{|c|c|c|c|}
\hline $\begin{array}{c}\text { No grup } \\
\text { material }\end{array}$ & Nama grup material & Massa jenis (gr/cc) & Prosentase berat elemen (\%). \\
\hline & & & \\
\hline & Daging bahan bakar & & $\begin{array}{c}90,556 \% \mathrm{Zr}, \\
1,567 \% \mathrm{U}-235, \\
6,267 \% \mathrm{U}-238, \\
1,610 \% \mathrm{H}\end{array}$ \\
\hline 2 & Celah udara & 0,10 & $76.6 \% \mathrm{~N}_{2} 23.4 \% \mathrm{O}_{2}$ \\
\hline 3 & Kelongsong SS-304 & 7,437 & $\left.70.92 \% \mathrm{Fe}, 19 \% \mathrm{Cr}, 10 \% \mathrm{Ni}_{1.6}\right)$ \\
\hline 4 & Pendingin & 1,00 & $11,11 \% \mathrm{H}, 88,89 \% \mathrm{O}_{2}$ \\
\hline 5 & Reflektor aksial & 2,10 & $100 \% \mathrm{C}$ \\
\hline
\end{tabular}

Susunan input program WIMSD4 adalah sebagai berikut:

“

Input program WIMSD4

CELL 6

SEQUENCE 5

NGROUP 192

NMESH 7

NREGION 707

NMATERIALS 5

PREOUT

INITIATE

ANNULUS 11.791

ANNULUS 21.872

Edi Triyono BS. 
ANNULUS 31.893

ANNULUS 45.04

MATERIAL $16.00300191 \quad 89.5558 \quad 235.41 .56682 \quad 238.46 .2672720011 .6099$

MATERIAL 20.001330041623 .41476 .6

MATERIAL 37.43730025670 .925219 .05810 .0120 .08

MATERIAL 41.003003200111 .1111688 .889

MATERIAL 52.10300412100

FEWGROUPS 12514192123262729545556575860616269

MESH 31112

FREE

NPIJAN 7

BEGINC

$7-1$

$\begin{array}{lllll}0 & 3.75 & 0.0 & 1.79 & 1\end{array}$

$\begin{array}{lllll}0 & 18.75 & 1.79 & 1.87 & 2\end{array}$

$\begin{array}{lllll}0 & 28.75 & 1.87 & 1.89 & 3\end{array}$

$\begin{array}{lllll}0 & 28.75 & 1.89 & 5.0 \quad 4\end{array}$

$\begin{array}{lllll}18.75 & 28.75 & 0.0 & 1.87 & 5\end{array}$

$\begin{array}{llllll}3.75 & 11.25 & 0.0 & 1.79 & 1\end{array}$

$\begin{array}{lllll}11.25 & 18.75 & 0.0 & 1.79 & 1\end{array}$

$\begin{array}{lllll}5 & 1035 & 0 & 1.79\end{array}$

$\begin{array}{llll}21 & 1035 & 1.79 & 1.87\end{array}$

$\begin{array}{llll}21 & 1035 & 1.87 & 1.89\end{array}$

$\begin{array}{llll}51035 & 1.89 & 5.0\end{array}$

* LEAKAGE CALCULATION

BUCKLING $0.01990 \quad 4.28 \mathrm{E}-3$

BEGINC

\section{HASIL PERHITUNGAN}

WIMSD4 digunakan untuk menentukan faktor multiplikasi neutron dan buckling kritis dari sel yang ruji-ruji luarnya divariasi dari $2 \mathrm{~cm}$ sampai dengan $5 \mathrm{~cm}$. Hasil perhitungan adalah hubungan antara ruji-ruji sel terhadap buckling material dan faktor multiplikasi neutron sebagai berikut:

Ruji-ruji kritis yang ditampilkan pada Tabel 3 diperkirakan dari persamaan (6) yang dituliskan lagi sebagai berikut:

$$
R^{\prime}=\left(\frac{\sqrt{B_{r}}}{2.405}\right)^{-1}
$$

Sedangkan jumlah sel bahan bakar maksimum yang dapat mengisi ruji-ruji kritis sel dapat diperkirakan sebagai berikut:

$$
N=\frac{\pi\left(R^{\prime}\right)^{2}}{\pi\left(R_{\text {sel }}\right)^{2}}
$$


Tabel 3. Hasil perhitungan program WIMSD4 terhadap sel bahan bakar.

( $\mathrm{B}_{\mathrm{r}}$ diperoleh dari ketetapan $\mathrm{B}_{\mathrm{aksial}}=3.1472 \mathrm{E}-3$ ).

\begin{tabular}{|c|c|c|c|c|c|}
\hline No & $\begin{array}{c}\text { Ruji-Ruji } \\
\text { Sel }(\mathrm{cm})\end{array}$ & $\mathrm{K}$ & $\begin{array}{c}\text { Br } \\
\text { Kritis }\end{array}$ & $\begin{array}{c}\text { Ruji-Ruji } \\
\text { Kritis }(\mathrm{cm})\end{array}$ & $\begin{array}{c}\text { Prakiraan } \\
\text { Jumlah Sel } \\
\text { kritis }\end{array}$ \\
\hline 1 & 2 & 1.5318 & $1.76 \mathrm{E}-02$ & 18.10 & 82 \\
\hline 2 & 2.25 & 1.5075 & $1.58 \mathrm{E}-02$ & 19.13 & 71 \\
\hline 3 & 2.31 & 1.5002 & $1.54 \mathrm{E}-02$ & 19.40 & 71 \\
\hline 4 & 2.5 & 1.4717 & $1.40 \mathrm{E}-02$ & 20.33 & 66 \\
\hline 5 & 2.75 & 1.4218 & $1.20 \mathrm{E}-02$ & 21.97 & 64 \\
\hline 6 & 3 & 1.3611 & $9.72 \mathrm{E}-03$ & 24.40 & 66 \\
\hline 7 & 3.25 & 1.2932 & $7.27 \mathrm{E}-03$ & 28.20 & 75 \\
\hline 8 & 3.5 & 1.2211 & $4.71 \mathrm{E}-03$ & 35.03 & 100 \\
\hline 9 & 3.75 & 1.1480 & $2.13 \mathrm{E}-03$ & 52.16 & 193 \\
\hline 10 & 4 & 1.0756 & $-4.42 \mathrm{E}-04$ & $\sim$ & $\sim$ \\
\hline 11 & 4.25 & 1.0056 & $-2.95 \mathrm{E}-03$ & $\sim$ & $\sim$ \\
\hline 12 & 4.5 & 0.9391 & $-5.36 \mathrm{E}-03$ & $\sim$ & $\sim$ \\
\hline 13 & 4.75 & 0.8759 & $-7.67 \mathrm{E}-03$ & $\sim$ & $\sim$ \\
\hline 14 & 5 & 0.8166 & $-9.88 \mathrm{E}-03$ & $\sim$ & $\sim$ \\
\hline
\end{tabular}

\section{PEMBAHASAN}

Elemen bakar reactor pada umumnya mempunyai faktor perlipatan neutron lebih besar dari $1\left(\mathrm{~K}_{\sim}>1\right)$ yang menunjukkan bahwa elemen bakar mempunyai potensi untuk melipat gandakan neutron yang terserap. Tempat penyimpanannya elemen bakar dibuat sedemikian rupa sehingga faktor multiplikasi neutron dari oleh sistem tempat penyimpanannya menjadi lebik kecil dari 1. Salah satu cara yang dilakukan adalah dengan membuat tempat elemen bakar yang satu dengan lainnya mempunyai jarak yang tertentu sehingga sifat multiplikasi neutronnya dapat seimbang dengan sifat kehilangan neutron dalam sistem. Jarak tersebut ditentukan berdasarkan pada analisis kekritisan sel elemen bakar, jaitu sel yang merepresentasikan ruang tempat penyimpanan elemen bakar. Dalam analisis ini sel didefinisikan sebagai elemen bakar dan lingkungan dalam penyimpanan seperti pada Gambar 1. Analisis kekritisan sel dikerjakan terhadap sel elemen bakar yang ruji-rujinya divariasi dari $2 \mathrm{~cm}$ sampai dengan $5 \mathrm{~cm}$. Perhitungan faktor multiplikasi neutron dikerjakan dengan menggunakan program WIMSD4 dan hasilnya ditampilkan pada Tabel 3.

Hasil perhitungan menunjukkan bahwa apabila ruji-ruji sel diperbesar sedangkan diameter elemen bakar tetap maka akan menghasilkan faktor multiplikasi neutron sel menjadi kecil. Demikian juga dengan hasil perhitungan buckling kritis yang diterjemahkan sebagai buckling radial dengan buckling aksial tetap, menunjukkan bahwa buckling kritis menjadi kecil apabila ruji-ruji sel menjadi besar atau dengan kata lain apabila ruji-ruji sel diperbesar akan menghasilkan volume kritis dari gabungan sel elemen bakar menjadi besar. Dari hasil pengamatan secara kuantitatif menunjukkan bahwa pada ruji-ruji sel $=2 \mathrm{~cm}$ menghasilkan faktor multiplikasi neutron sel $=1.53$ kemudian apabila ruji-ruji sel diperbesar sampai dengan $4.5 \mathrm{~cm}$ maka hasil perhitungan faktor multiplikasi neutron menjadi kecil sehingga pada ruji-ruji $4.5 \mathrm{~cm}$ 
terhitung faktor multiplikasi neutronnya menjadi 0.94. Ruji-ruji $4.5 \mathrm{~cm}$ adalah merupakan ruji-ruji minimum yang perlu disediakan dari masing-masing elemen bakar dalam tempat penyimpanannya agar tidak terjadi kekritisan. Apabila ruji-ruji minimum dari masing-masing elemen bakar ini tidak dapat dipenuhi maka sebagai batasan kedua adalah jumlah elemen bakar dalam volume kritisnya dibuat lebih kecil dari batas massa kritisnya. Batas sub-kritikalitas yang ditetapkan berdasarkan pada batasan volume kritisnya tidak dapat menjamin secara lengkap sub-kritikalitas sistem, karena sifat multiplikasi neutron dari masing-masing sel lebih besar dari 1 dapat menimbulkan kemungkinan kritis pada penggabungan tempat penyimpanan menuju pada kapasitas yang lebih besar.

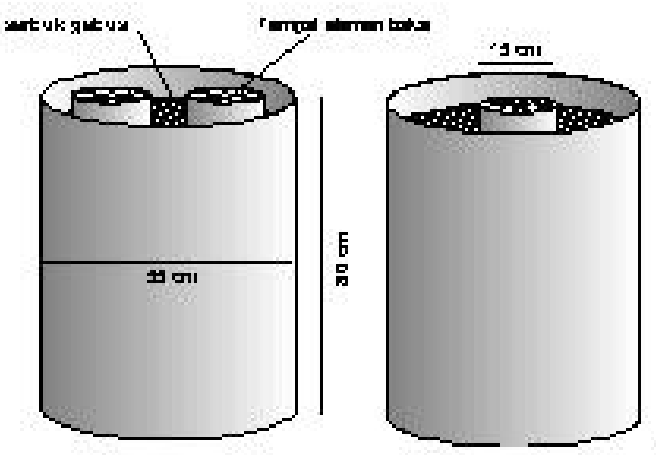

a). Drum elemen bakar baru

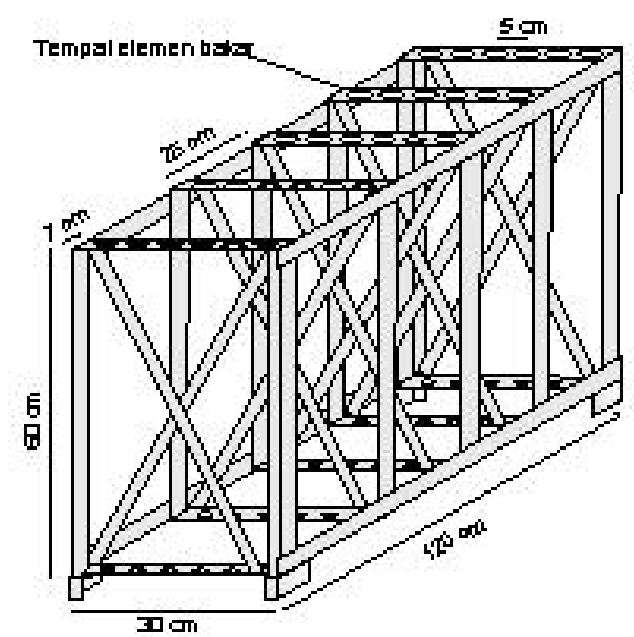

c). Rak elemen bak ar bek as di Bulk shielding.

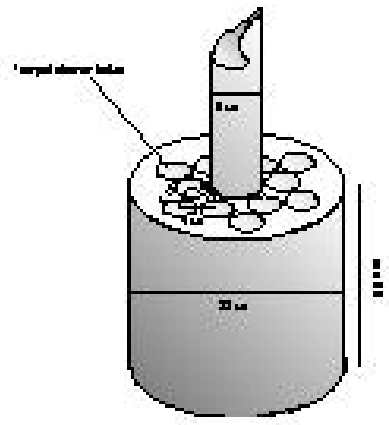

b). Inadiator ganma dengan elemen bakar bek as

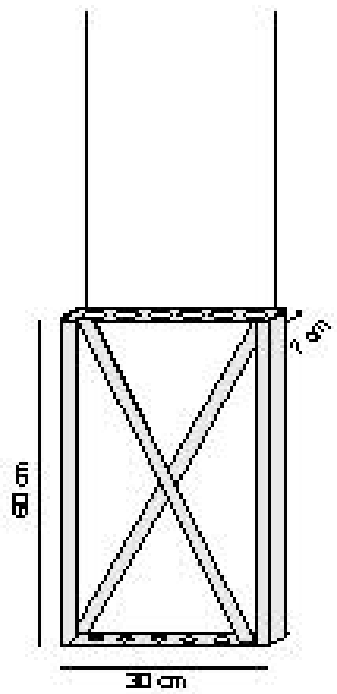

d). Rak sementara elemen bakar di tarki reaktor.

Gambar 2. Ragam tempat elemen bakar yang tersedia di reaktor Kartini 
Sifat multiplikasi neutron dari suatu elemen bakar adalah spesifik terhadap komposisi material dan konstruksi elemen bakarnya, sehingga hasil perhitungan sub-kritikalitas suatu jenis elemen bakar tidak dapat disamakan dengan sub-kritikalitas elemen bakar jenis lainnya.

Apabila ditinjau ragam tempat penyimpanan elemen bakar yang tersedia di reaktor Kartini (Gambar 2), dapat disimpulkan bahwa seluruh tempat penyimpanan elemen bakar tidak menyimpang dari hasil perhitungan. Ditinjau dari jarak antar elemen bakar dalam tempat penyimpanannya mempunyai posisi yang lebih rapat dari jarak antara elemen bakar yang disyaratkan dari hasil perhitungan WIMSD4, akan tetapi masing-masing tempat penyimpanan tersebut mempunyai batas ruang tempat penyimpanan yang lebar sehingga jumlah elemen bakar yang dapat diisikan pada tempat penyimpanan tersebut tidak melebihi batas massa kritisnya. Sebagai contoh drum elemen bakar baru mempunyai kapasitas $2 \mathrm{x}$ 6 elemen bakar, masing-masing 6 elemen bakar ditempatkan dalam kisi-kisi yang rapat dengan jarak antara poros elemen bakar $4 \mathrm{~cm}$. Dipandang dari perhitungan kekritisan sel dapat diketahui bahwa sel yang terdiri dari 6 elemen bakar yang ditempatkan rapat akan menghasilkan faktor multiplikasi neutron yang lebih besar dari 1, akan tetapi masing-masing 6 elemen bakar tersebut ditempatkan dalam kisi-kisi tempat elemen bakar yang terpisah lebar dalam sebuah drum dengan sekat diantaranya diisi dengan serbuk gabus. Diameter drum $56 \mathrm{~cm}$ sehingga geometri drum dapat menjaga sub-kritikalitas elemen bakar yang ada di dalamnya berdasarkan pada syarat batas massa U-235 yang tidak memenuhi volume kritisnya.

Tempat penyimpanan elemen bakar bekas di Bulkshielding berbentuk Rak elemen bakar dengan ukuran $120 \mathrm{~cm}$ x $60 \mathrm{~cm}$ x $30 \mathrm{~cm}$ (Gambar 2c). Kapasitas Rak adalah 30 elemen bakar yang berjajar $5 \times 6$ elemen bakar dengan masing-masing jajar elemen bakar berjarak $25 \mathrm{~cm}$. Jarak terpendek antara poros elemen bakar adalah $5 \mathrm{~cm}$. Rak elemen bakar bekas ini aman terhadap kekritisan berdasarkan pada kriteria massa U-235 yang tidak melebihi volume kritisnya.

Irradiator gamma dengan 12 elemen bakar bekas. Fasilitas ini berbentuk silinder dengan diameter $22 \mathrm{~cm}$ dan tinggi $60 \mathrm{~cm}$, dapat diisi dengan maksimum 12 elemen bakar bekas (Gambar 2b). Fasilitas irradiasi gamma terdapat pada poros silindernya. Kondisi subkritikalitas perangkat irradiator gamma ini dijaga oleh volume silinder yang tidak dapat diisi elemen bakar melebihi massa kritisnya.

Rak sementara elemen bakar di tanki reaktor (Gambar 2d). Fasilitas ini berbentuk Rak dengan kapasitas 6 elemen bakar yang tergantung pada dinding tanki reaktor. Rak elemen bakar ini merupakan tempat sementara elemen bakar yang mengalami perpindahan di teras reaktor. Posisi Rak elemen bakar adalah berdiri sendiri dan tidak bergabung dengan Rak elemen bakar lainnya, sehingga subkritikalitas terjaga oleh jumlah kapasitas elemen bakar yang tidak melebihi volume kritisnya.

\section{KESIMPULAN}

Hasil perhitungan kekritisan sel elemen bakar menunjukkan bahwa batas volume kritis sel adalah elemen bakar yang dikelilingi air sehingga membentuk ruji-ruji $4.5 \mathrm{~cm}$ dengan $\mathrm{K}_{\sim}=0.94$. Apabila ruji-ruji sel menjadi lebih besar dari $4.5 \mathrm{~cm}$ maka faktor multiplikasi neutron yang dihasilkan oleh sel menjadi lebih kecil dari 0.94 sedangkan apabila ruji-ruji sel menjadi lebih kecil dari $4.5 \mathrm{~cm}$ maka sifat multiplikasi neutron sel akan lebih besar dari 0.94 dan dapat melebihi 1. Dari hasil peninjauan semua tempat penyimpanan elemen bakar dan dibanding- 
kan dengan hasil perhitungan dapat diperoleh kesimpulan bahwa seluruh tempat penyimpanan memenuhi syarat subkritikalitas karena volume tempat penyimpanan elemen bakar jauh lebih besar dari kapasitas jumlah elemen bakar yang dapat diisikannya, dengan kata lain volume kritis tempat penyimpanan elemen bakar tidak pernah dilampaui oleh elemen bakar yang diisikannya..

\section{DAFTAR PUSTAKA}

1. M.T. SIMNAD, The U-ZrH ${ }_{x}$ Alloy: Its Properties And Use In Triga Fuel, GA Project No. 4313, General Atomic, 1980.

2. N. TOMSIO, Characterization of Triga Fuel, GA Project No. 3442, GA Technologies Inc. 1986.

3. JOHN R. LAMARSH, Introduction to Nuclear Reactor Theory, Addison-Weshley Publishing Company, 1972.

4. Ir. PRAYOTO M.Sc Ph.D., Pengantar Teori Reaktor, Fakultas Teknik Universitas Gadjah Mada, Jogjakarta.

5. M.J. HALSALL and C.J. TAUBMAN, The '1986' WIMS Nuclear Data Library, Reactor Physics Division, AEE Winfrith. 1986 